\title{
TEFL educational principles: a proposal for changing times
}

\section{Principios de la enseñanza de la lengua extranjera: una propuesta para tiempos cambiantes}

\author{
Ximena Bonilla Medina \\ Universidad Distrital Francisco José de Caldas \\ Bogotá -Colombia \\ E-mail:Ximenabvonilla@gmail.com
}

Received: 22 - Sep - 11 / Accepted: 10 - Aug -12

\begin{abstract}
:
Today's society is influenced by new information technologies, which cause important sociological changes that impact education. As such, the field of EFL today demands different abilities and attitudes from teachers. This paper has two objectives: first, to initiate a reflection on the EFL teachers' role, taking as an assumption that teachers have been influenced by cultural background experiences in their professional development and that this has caused them to develop a narrow view of ideal methods which may not be appealing for situations, and second, to propose three principles in foreign language teaching that will allow seeing EFL tasks from a wider view: 1) evaluating what comes from one's cultural background that conforms to a general understanding of what teaching is, 2) re-shaping the teachers' role in order to align with society's demands and 3) assuming a dialogic process to building classroom strategies for language teaching and learning.
\end{abstract}

Keywords: teaching a foreign language, cultural background, teachers' role, dialogic process

\section{Resumen}

La enseñanza del la lengua extranjera está exigiendo diferentes habilidades y actitudes de los profesores debido a nuevas dinámicas de la sociedad. Hay dos objetivos en este artículo: primero, motivar una reflexión sobre el rol de los profesores de inglés cuya influencia por antecedentes culturales en su desarrollo profesional ha sido percibido de forma limitada a los ideales de un método. Segundo, proponer tres principios para la enseñanza de la lengua extranjera que sirvan para darle una visión mas amplia que permita acomodarse mejor a los requerimientos de la actualidad: 1 . Evaluar lo que viene de nuestros antecedentes culturales y que conforman nuestro entendimiento general de cómo se debe enseñar, 2. Reformar el rol del maestro para mediar con las exigencias de la sociedad actual y 3 . Asumir un proceso dialógico para construir estrategias en la enseñanza y aprendizaje de la lengua.

Palabras clave: enseñanza de la lengua extranjera, antecedentes culturales, el rol del maestro, un proceso dialógico.

\section{Résumé}

L'enseignement de la langue étrangère demande des compétences et des attitudes différentes chez les enseignants du fait des dynamiques nouvelles de la société. Cet article a deux objectifs : le premier, de promouvoir une réflexion sur le rôle des enseignants d'anglais, dont l'influence, à cause des antécédents culturels dans son développement professionnel, a été perçue d'une manière limitée aux idéaux d'une méthode. Le deuxième, de proposer trois principes pour l'enseignement de la langue étrangère qui permettront de lui donner une vision plus élargie afin de mieux s'adapter aux besoins d'aujourd'hui : 1. Évaluer ce qui relève de nos antécédents culturels et qui fait partie de notre compréhension générale de la façon dans laquelle il faut enseigner ; 2 . Modifier le rôle de l'enseignant afin de l'adapter aux demandes de la société actuelle ; 3 . Entamer un démarche de dialogue pour construire des stratégies dans l'enseignement et l'apprentissage de la langue.

Mots clés: enseignement de la langue étrangère, antécédents culturels, le rôle de l'enseignant, une démarche de dialogue. 


\section{Resumo}

O ensino da língua estrangeira está exigindo diferentes habilidades e atitudes dos professores devido a novas dinâmicas da sociedade. Há dois objetivos neste artigo: primeiro, motivar uma reflexão sobre o papel dos professores de inglês cuja influência por antecedentes culturais no seu desenvolvimento profissional foram percebido de forma limitada aos ideais de um método. Segundo, propor três princípios para o ensino da língua estrangeira que sirvam para dar-Ihe uma visão mais ampla que permita acomodar-se melhor aos requerimentos da atualidade: 1. Avaliar o que vem dos nossos antecedentes culturais e que conformam o nosso entendimento geral de como se deve ensinar, 2. Reformar o papel do professor para mediar com as exigências da sociedade atual e 3. Assumir um processo dialógico para construir estratégias no ensino e aprendizagem da língua.

Palavras chave: ensino da língua estrangeira, antecedentes culturais, o papel do professor, um processo dialógico 


\section{Introduction}

Foreign language teaching methods emerged in the mid-1800s with grammar translation, which was the process of teaching based on translating written texts. At that time, discussions on teaching methods also arose. After the grammar translation method received an anticipated criticism by Marcel, Pendergast and Gouin (1886, cited in Richards and Rodgers, 2001) in a demand for more emphasis on oral proficiency, the studies became focused on looking for suitable methods which favor communication. However, this search also showed a tendency to develop more accuracy than fluency. This can be observed in the principles of methods such as audio-lingualism, which teaches through the practice of drilling, but limits communication to the accuracy of pronunciation and correct sentences. With the arrival of this method, two problems originated. First, the tendency to limit the language learning to the language itself and second, the teachers' dependence on having a method to be able to overcome the problem of lack of student communication. From my point of view, the current problem does not rest in having an appropriate method for teaching language, but rather in combining principles which constitute the basis for teaching more in accord with the demands of society and its changing nature. This paper proposes EFL teaching that goes beyond the linguistic and functional paradigm more appropriated to the new sensitivities that are part of current society. Through this paper I propose three principles for EFL teaching. The first has to do with uncovering what comes from one's cultural background that conforms to a general understanding of what teaching is. The second is re-shaping the teachers' role in order to match with society's demands. And the third is assuming a dialogic process of building classroom strategies for language teaching and learning.

\section{Uncovering Cultural Beliefs About Teaching}

The first principle, uncovering cultural beliefs about our background in teaching to understand what teaching is, requires an inspection of cultural effects on one's behavior. Culture can influence individuals by having them create ties to the past which unconsciously makes them behave and accept the reality that surrounds them (Lortie, 1975; Alvarez, 2005; Brislin, 1993; Freeman and Johnson, 1998; Gutierrez, 1996; Cruz, 2007). This cultural influence is characterized by the construction of imaginary signifiers, representations, and ideologies that are shared with members of the same community. It is also characterized by an undeniable strength in confidence regarding past experiences and the building up of assumptions of a certain reality. Teachers as individuals have cultural beliefs that have been transmitted from generation to generation; this, in turn, has perpetuated what teachers think about teaching a foreign language. Teachers repeating the model of teaching as they were taught is referred to by Lortie (1975) as the "apprenticeship of observation". An example of this detail is evident when teachers steadfastly adhere to a "method" to teach language. Unfortunately, this creates a weakness in creating and innovating new classroom practices because, as stated by Kumaravadivelu (2003), these methods are static and do not take into account the teaching context features which may change their effectiveness. As a consequence, teachers start to believe that language teaching is only valid when a method is applied and it is difficult for them to establish an authentic proposal that redesigns what happens in a specific situation.

These assertions prove teachers' dependence on using a method and lead us to think that, more than revising old methods, they need to evaluate their own culturally conceived beliefs about the teaching process in order to be able to frame their new own theories (Kincheloe $\varepsilon$ Steinberg, 1998). In other words, if teachers understand the role that the cultural environment has on their conceptions, they could be able to identify their own abilities and 
weakness as individuals and start a re-building procedure of what teaching could be (Farrell, 1998). The process of evaluating those cultural beliefs would also involve the understanding of the teaching task as a multidimensional activity in which the main actors are not only the teacher but also students. Then, evaluating cultural beliefs also involves both characters and the cultural elements each brings to the classroom. Thinking of a concrete illustration, teachers can use examples in class to explain what a 'taboo' is. The teachers' explanations can construct meaning for themselves and they can be meaningful as they are used to understand it as a taboo; however, students from another generation might think the taboo is no longer a taboo, as everybody can talk about it freely. To mention some, this can be seen in topics related to homosexuality, which has turned into the LGTV community and is no longer a taboo or marriage which was before conceived as a mother and father and nowadays can be stepmother or father and the diverse combinations that this has brought. In the teachers' time certain kind of examples bringing up this labels could have been meaningful, but for students those examples could be meaningless, since they have not experienced the same historical/social context. Instead of becoming a meaningful learning opportunity, this model can create a gap of misunderstanding with the consequence of boredom or another adverse reaction from students.

In order to start the revision of cultural beliefs, the exercise has to do first with reflection. Reflection in teaching has been proposed by several authors like Schön (1991), Richards E Lockhart (1994), and Alwright (1991), who state that one's beliefs are the base of teaching practices and, through reflecting on them, teachers can make sense of classroom dynamics and make informed decisions (Bonilla \& Mendez, 2009). In other words, it is through reflection that teachers understand those cultural beliefs, and through the process of understanding the way they act, they take advantage of their own styles to enhance their teaching skills. Reflection also enables teachers to evaluate how the teaching context is not being favored by the their instruction and invites them to adjust to different conditions or different times. Reflection might help teachers to bridge theory to practice (Dewey, 1938; Wallace, 1991; Richards E Lockhart, 1994; Gutierrez, 1996; Farrell, 1998; Loughran, 2002; Tsui, 2003) as all actions taken in class are mediated by careful decision making; a teacher has to make decisions all the time - decisions in planning, in choice of text-book, in classroom activities, etc. (Richards \& Lockhart, 1994). If a teacher knows why these decisions are made, this is a reflection of clear principles in her mind. In other words, teachers relate directly what theory is into practice.

After understanding the relationship between reflection in teaching language with cultural beliefs, a second step involves using that reflection to uncover language teaching myths that have become part of teacher's cultural schemata. Beliefs on language teaching can be divided into three general types. The first sets of beliefs are related to language, the second about teaching, and the third about learning (Richards $\mathcal{E}$ Lockhart, 1994). All those beliefs bring ideas of how language should be taught and consequently, myths have been associated with them.

Myths about language can be summarized as follows: there is only one standard language and consequently there are 'ideal' speakers of it (Byram \& Risager,1999). This means that language is put on a pedestal as well as the speakers of that language. Under this conception, there is only one correct use of language and native speakers are idealized to speak that standard language. In this view, nowadays the outer and expanding circle which Rubby and 
Saraceni (2006) and other authors reference when they refer to people from countries who are speaking English on a daily basis (such as English as a lingua franca societies), is neglected. In the same vein, skills are seen as the basis for the development of language proficiency (Kumaravadivelu, 2003) and language acquisition is an organized linear progression, as it was first debated by the differentiation between 'learning' and 'acquisition' made by Krashen in 1982.

In the case of teaching, it has long been thought that teaching English is teaching the language itself, so teachers center their attention on language forms and functions, overlooking social and cultural factors generated by this interrelationship. Also, teachers consider they are the ones responsible for students' learning. Consequently they feel they must take the control of the class and that may guide indirectly to authoritarian behavior; something that nowadays is unwelcome in any classroom. Finally, in the case of learning, teachers tend to believe that students learn everything being taught, that learners need to be guided all the time throughout the learning process, and that they need to practice extensively in class because they have no opportunity to practice outside. That is why they consider code-switching to be dangerous for language learning (Kumaravadivelu, 2003). Obviously those myths described above are culturally constructed; hence, they have become part of the background teachers possess and reproduce when they teach. For this reason, it is expected that the exercise of reflection might encourage teachers to understand that those myths should be discovered to tolerate changes, open minds and try new strategies that break with common and traditional thoughts.

\section{Re-shaping the Teacher's Role in Order to Mediate with society's demands}

The second principle presented here is grounded in the fact that we are undoubtedly living a new age of education. Since technological devices have become part of our lives, many different ways of thinking have been generated (McLaren, 1994). Current students are being educated with the influence of those instruments which likely bring the in-flow of many cultures. New technologies have been the means for new generations to have a more globalized idea of the world. Following this idea, it is necessary for teachers to remodel their roles and that implies that they are able to use technological devices reshaped by new ways of thinking such as intersubjectivity, collaborative knowledge construction, multicultural understandings, etc. Simply breaking the myths that teachers possess in relation to language teaching and learning would not be enough to take an active role in this endeavor, though. Teachers nowadays need to be aware of the new ways of communication that young people exhibit. In other words, teachers' disciplinary knowledge is currently not enough. Teachers need to develop an interdisciplinary agenda in their teaching. For foreign language teachers that means using the language as a means to understand how these new ways of communication are creating new realities for students and making them realize that it is happening, while at the same time, using the language to express what they feel.

With these new changes in the world, the teaching of a language seems to be taught as a single discipline, based on the identification of patterns, underestimating the nature of understanding it as a multidimensional, complex instrument that goes beyond a text and that involves interpersonal elements. These multiple dimensions become part of individuals' lives, their political, social and cultural profiles. Language taking all these dimensions is known as ideational. From this outlook, language enables individuals to express what they feel and think about what they live (Halliday, 1985 
cited in Kumaravadivelu, 2003). This implies that the foreign language teachers' role might be characterized by intercultural competence, innovative, risking attitudes and a critical view on teaching. The union of those talents, which I will explain more in detail below, allow teachers to be in contact with the classroom environment sensitive to the conditions that can favor or obstruct the learning process. At the same time, teachers can become resourceful to reaccommodate methodologies and get back on track desired goals if processes are not working well.

One of the ways to start reshaping the teachers' role to meet society's demands is to develop intercultural competence. As our world nowadays is becoming more open to other cultures due to globalization and the influx of new technologies, developing intercultural competence is necessary to understand contemporary sociocultural behaviors, which impl an overlapping of cultures. In this sense, boundaries among cultures are blurred and it is often difficult to recognize if a socially recognized symbol is part of one culture of another (McLaren, 1997). For instance, young people influenced by information disseminated on the internet may copy the behaviors of others and produce new subcultures (Canclini, 2006). That is a phenomenon which leads to homogenization, so, as teachers, we must be able to act according to their new expectations and beliefs.

In the field of language teaching, interculturality has been seen as the ability to understand two different cultures. Consequently, it is also commonly believed by foreign language teachers that interculturality means putting the subjects' own culture in contrast with the target language culture (Nieto, 2002). This definition is taken either as the comparison of the two cultures involved in terms their language use, or the comparison of the cultural artifacts produced in each (Kramsch, 2008). As such, this vision generally neglects that interculturality is a concept that involves values, ideas and beliefs of two or more cultures and that interculturality does not necessarily mean cultures identified by the use of two different languages. Interculturality covers the inter- and intra-relation of any culture, which can sometimes be immersed in a culture where a unique language is spoken.

Thus, in order to reshape the English teacher's role, it is required to understand first, from a broader perspective, what interculturality is. In order to start, teachers need to consider that there are two spheres that integrate intercultural competence; they are intercultural communication and intercultural awareness (Alvarez \& Bonilla, 2009). In the first case, intercultural communication has to do with the ability to manipulate communication with a person who belongs to a different culture. This means that one is able to understand how cultural differences work in a particular conversation and how each individual can mediate to avoid misleading communication. In the second case, cultural awareness deals with the capacity to understand cultural schemata, taking account of individuality without disregarding the other's identity and cultural outline (Byram, 2000).

Deepening into the concept of interculturality, it also entails the idea that language is not isolated from, but a part of, culture. This idea is supported by the conception that teaching the language must focus on use, since in real situations it is never 'out of context'. Bearing in mind that culture is part of most contexts, communication is rarely culture-free (Cruz, 2007). That is why some language teachers focus their attention on highlighting cultural artifacts or behaviors that originate in the target culture (Galloway, 1985). Although this perspective embraces a concept of interculturality, and even if there is an exercise of comparisons between the two cultures (the mother 
tongue and the target language), it is necessary to include other cultures in the analysis which can be blended into the classroom environment. This means that every student embodies a dissimilar culture, every family background is diverse, every custom and tradition could be different (Nieto, 2002) and the classroom is a meeting point where all those cultures converge and create a new culture.

If teachers understand the multiplicity of dimensions involved in the concept of culture and interculturality, they will notice more nuance in their classroom dynamic and will be more open to changing and reforming what they have done in the past. These teachers can see student multiculturality as a new opportunity to build up their teaching ability. Then any teacher, not only the language teacher, puts interculturality into practice. They will be the people who can tolerate difficult situations, who have a high level of sensitivity to student needs and who can communicate in the language that students need. Kramsch (2001) says that an intercultural speaker is able to read the cultures from an outsider viewpoint and is able to see it from different perspectives. To be intercultural is a value that empowers teachers and language teachers to communicate and understand students' realities better. Thus, in order to deal with society's demands, a language teacher must be able to understand her students' world through her interactions with them.

Another feature to reshape teachers' role to to mediate with society's demands is as an innovator. For a teacher to be an innovator, certain characteristics should be kept in mind. Individuals are bound to context, including beliefs and thoughts that are socially constructed (Van Dijk, 1986). Innovating is an exercise of realizing those beliefs and breaking rules, trying new things, changing paradigms; it is a never-ending process of building and rebuilding what we feel confident with (Kincheloe E Steinberg, 1998), of re-thinking what we already thought was true. Wink (2000) makes an important contribution regarding a transformational view of pedagogy, She says that education has overcome the era of traditional teaching and teachers are now more on the side of generative views of pedagogy which place more importance on the individual construction of knowledge, and the guidance from teachers is more to assist than to direct. She proposes that teaching nowadays should place students in a more transformational role, in which they not only learn and construct knowledge by themselves but also develop their own abilities in order to change their context as social agents.

In the same line of thought, Kumaravadivelu, (2003) declares that teachers today should be more active in encouraging students to be open to the world and understand that language development is another way to acquire power for students. An innovative language teacher must provide the space for students to see language learning as more than a list of codes or developing abilities to communicate and meaningfully help students realize that they can transform realities with its use. To make this idea concrete, teachers can encourage students to analyze the meaning that language forms acquire in different contexts as well as the meaning that is gained depending on the way language is used to address different kinds of people in different situations.

A teacher who reshapes her role as an innovative foreign language teacher ventures to work on topics that are not traditionally used in school. From a more holistic view of language teaching, language is seen as a means of communication and it is impossible to teach language if it is not situated in content-based approaches. That means it is indispensable to address a topic when teaching language; otherwise it would be difficult for communication to take place. It would become, as said before, 
the myth of teaching the language itself. Having realized this, it is mandatory to think what the teaching topics should be. Even if it sounds like a simple question, for a language teacher as an innovator, this question is of paramount importance. The choice of topic would reflect the formation of goals stated for students. Consequently, the step of topic selection would constitute another source for innovation.

Reshaping the teacher's role as an innovator also involves awareness on the fact that the concept of innovation in foreign language education has changed with time along with the conditions of society and this has brought different conceptions on the relevance of topics to be used. Innovation in language teaching after the boom of the communicative approaches in the 1950's centered around language for communication and topics were tied to situations. Then, around the 1980 `s new methods started to arise, among them content-based instruction, whole language, cooperative learning, project-based learning and the task-based approach (Richards \& Rodgers, 2001; Willis, 1996). As these methods attempted to develop communication, they naturally contained what topics should be used for English curricula; subsequently, adjustments in syllabus design were made to meet that new need. Syllabi were revisited to develop not only communicative functions but also notions, topics and ideas. They moved from dedicating time to understand ways of expressing verbal promises, short conversations and others, to teaching concepts of measurement or topics such as the environment, nature, etc. Educational institutions, publishing houses and teachers organized topics for students based on the idea of what they felt was necessary for them to learn.

This contextualization is important for teachers as innovators as it brings up the awareness of the fact that ideas of topics and contents do not always come from the teacher. As the world continues evolving, ideas of liberty and dignity have been taking a more significant place (ONU, 2009); thus, new demands in education need to be figured out. The world needs more autonomous individuals who are able to make decisions and control themselves, who can also build up their individual life projects, that could lead to a greater respect for the interdependence among people in a shared world. So, teachers need to open opportunities to students to propose what they want to learn or what they need. These new thoughts have structured education in a different way, so individuals can have a voice to participate in what they choose to live and learn.

The growing interest in individual participation has impacted several perspectives in education as well as in the teacher's role as an innovator. One of these perspectives has to do with power relationships extended inside the institutions challenging traditional models of authority between teachers and students. For example, students are now allowed to express what they feel in class and propose individual manners of learning that they were not permitted before. Aspects of participation and democracy in which students' participation in curriculum development started to be seen as a manifestation of considering democracy and equality. From these perspectives, decisions on the syllabus and the curriculum were disputed arguing that students cannot be denied the opportunity to choose what they want to learn (Beane, 2005). In foreign language teaching, this is reflected in students creating their own paths for learning and by deciding on topics which they consider meaningful. Within those describing their nuclear family, for example, talking about their experiences and others became appropriate (Freire, 2000; Shor, 1996). As a result, an important demand for teachers as innovators needs to take part in those processes of democracy and open spaces where students 
get the opportunity to give opinions, state points of view and express their desires in terms of education. This becomes relevant as students will feel they are recognized as valuable beings that are able to propose to help their context.

The force of these new ideologies in the evolution of our society has brought consequences not only for decision-making regarding topics of the curriculum and syllabus but also in the dynamics inside the classroom. In the foreign language classroom, these changes in power relationships are represented in the teachers' and students' roles assumed in the lesson. In the age of communication, teachers worried about the topics they had to choose to teach, but in the new generation, teachers have to open a place for students to make decisions on anything related to their education-related concerns (Wink, 2000). In this sense, it is vital that teachers as innovators be able to provide possibilities to students that encourage them to have a choice in their formation. Teacher innovators should also balance their voice in the class for students to express what they want to say - they may find in the language a means to develop their students' personality and their own.

Another requirement to reshape the teacher's role to mediate with society's demands has to do with acquiring critical visions to observe and detect opportunities for change. Teachers with these characteristics are able to understand classroom realities and make informed decisions over their teaching-learning. Moreover, critical educators are able to develop personal theories based on personal stances that directly reveal their philosophy of teaching (Crooks, 2003). For example, a teacher who is socially sensitive may consider it relevant to have an individual, subjective and socio-affective path for learning. This can involve bringing examples of her own life to explain and make students understand how language works in daily real life situations. The awareness on these philosophies enables teachers to become more critical with their teaching: they can adjust new strategies that permit expansion of knowledge naturally instead of accumulating prescriptive steps and formulas which are not really meaningful for each particular case. Teachers that are critical are able to develop alternative plans when things are not working; they are able to interpret and account for decisions made in the class. They see education in the context of the general society and posit students as social agents to be able to transform it (Hinchey, 2004).

\section{Assuming a dialogic process of building classroom strategies}

The third principle that I propose goes more appropriately with the demands of society and has to do with assuming dialogic classroom strategies. This principle implies understanding the dialogic process in the EFL classroom in its dynamics and organization. For many people, this concept could be associated with what we traditionally understand by negotiation of meaning (LarsenFreeman, 2000). However, dialogism in this paper is treated in an extensive sense in which the process is not limited to finding ways to increase language proficiency. According to Freire (2000), the world is the essence of dialogue itself, since its nature includes creativity, confidence, democracy and critical views and they are vital in human development. In this sense, the dialogue that the English teacher promotes does not only provide information, but transforms individuals and enable them to recognize the power of language by their interventions.

Freire affirms that dialogue is an opportunity for human beings to recognize a tri-dimensionality of themselves; the past, the present, and the future. In this view, dialogue activates in teachers the capacity to uncover myths about their profession and strengthen the ability to be prepared, react to unexpected situations and 
think of new expectations. Thinking of people and elements involved, this concept of dialogism includes teachers and learners, classroom procedures, language learning perspectives or power relationships. All of these factors convert this dialogue in the reflective exercise of continues change. For critical and effective dialogue, new ways of working involve more collaboration and team work meaning that the construction of knowledge is not the core in one individual; anybody can have the knowledge or create it in any place (Shor, 1996).

To initiate dialogue, language teachers need to formulate questions that deal with their own behavior in the classroom. For example, "What are my educational purposes?" "What are the materials and human resources?" "How can I describe my context?" "What could be meaningful for my students?" "What would my focus be?" "How would I manage the language?" After asking these questions, the teachers' roles as intercultural, innovative and critical individuals come into play. Principles underlying the language learning objectives should enhance students' competences in all senses, not only language. Some competences would include encouraging students to embrace autonomy which means pushing them to be able to make decisions not only in language learning but also in their life, to able to transform their realities, decode multiple types of languages that are present in daily life such as the one of new technologies, and to maximize learning opportunities in and outside the classroom. It is crucial to invite students always to realize that language means power to understand the world and to be able to read it from different perspectives.

\section{Conclusion}

English teaching is a complex and multidimensional action which, as well as other human actions, has been conceived of socially and culturally. These conceptions are attached in the beginning on paradigms of methods and they have a strong influence on present teaching practices. These routines have been affected by the common concern of developing the foreign language learning based on the improvement of language accuracy, which is often cover under the aegis of reaching communicative goals.

As educators of today's civilization, teachers need to reshape their labor by evaluating cultural static beliefs about ways English should be taught. This implies an exercise of reflection that makes them able to become aware of the cultural background which can influence their ideas, imaginations or conceptions they have for what constitutes appropriate teaching. The second principle: redefining roles in order to match with society's demands requires promoting intercultural, critical and innovative skills. This means understanding diversity and the coexistence of cultures, developing consciousness of the elements included in the teaching task and being able to propose different changes depending on the conditions given for each pedagogical situation. Finally, teachers should follow a dialogic process of building classroom strategies that favor reflection, creativity and critical viewpoints of multiple aspects involved; a process that has to do with the permanent reflection in which emergent situations can provoke adequate changes in order to improve any pedagogical action.

\section{References}

Alvarez, J. (2005) An approximation to teachers' knowledge base through teachers' reflection. Unpublished manuscript. Universidad Francisco José de Caldas.

Alvarez, J. \& Bonilla, X. (2009). Addressing culture in the EFL classroom. A dialogic proposal. Profile journal. 2:151-170.

Alwright, D. (1991) Focus on the language classroom. Cambridge: Cambridge University Press. 
Beane, J. (2005) La integración del currículo. España: Ediciones Morata.

Bonilla, X. \& Mendez, P. (2008) Mentoring in pre-service teaching: from reflection on practice to a didactic proposal. Actualidades Pedagógicas. 52 (7):79-90.

Brislin, R. (1993) Understanding culture's influence on behavior. East West Honolulu.Center, Hawaii.

Byram, M \& Risager, K (1999) Language teachers, politics and cultures. Canada: Multilingual matters Ltda.

Byram, M. (2000) Intercultural communicative competence. The challenge for language teacher training. In Mounford, N. and Wadham-Smithm, $\mathrm{N}$ (eds). British studies: Intercultural perspectives. 95-102. Edinburgh: Longman in Association with the British Council.

Canclini, N. (2006) Diferentes, desiguales y desconectados. Mapas de la interculturalidad. Gedisa.

Crooks, G. (2003) A practicum in TESOL. Professional development through teaching practice. Cambridge Language Education:UK

Cruz, F. (2007). Broadening minds: exploring intercultural understanding in Adult EFL learners. Colomb. Appl. Linguist. J. 9(10):144-173.

Dewey, J. (1938). Experience and education. New York:Mc Millan Publishing House.

Farrell, T. (1998). Reflective teaching the principles and practices. English Teaching Forum. 36(4):10-17.

Freeman, D. \& Johnson, K. (1998). Reconceptualizing the knowledge base of language teacher education. TESOL Quarterly, 32 (3):367-417

Freire, P. (2000). Pedagogy of the oppressed. New York. Continuum.

Galloway, V. (1985). A design for the improvement of the teaching of culture in the foreign language classrooms. ACTFL project proposal.

Gutierrez, G. (1996). Student foreign language teacher's knowledge growth. In Freeman, D. and Richards, J. (eds) Teacher learning in language teaching. (50-78) Cambridge: Cambridge University Press.

Hinchey, P. (2004) Becoming a critical educator. New York. Peter Lang.

Kincheloe, J \& Steinberg, S. (1998). Unauthorized methods. New York: Routledge.

Kramsch, C. (2001). Intercultural communication. In R.
Carter \& D., Nunan (Eds), The Cambridge guide to teaching English to speakers of other language. Cambridge: Cambridge University Press.

Kramsch, C. (2008). Context and culture in language teaching. Oxford University Press: UK.

Kumaravadivelu, B. (2003) Beyond methods: Macrostrategies for language teaching. London: Yale University Press.

Larsen-Freeman, D. (2000) Techniques and principles in language teaching. Oxford:UK.

Lortie, D. (1975) Schoolteacher: a sociological study. Chicago:University of Chicago Press.

Loughran, J. (2002) Effective reflective practice. In search of meaning in learning about teaching. Journal of Teacher Education, 53 (1):33-43

McLaren, P. (1994). Pedagogía crítica, resistencia cultural y la producción del deseo. Aique Ediciones. Argentina.

Nieto, S. (2002) Language, culture and teaching. Critical perspectives for a new century. Lawrence Erlbaum Associates. Inc. USA.

ONU, (2009). http://www.un.org/es/documents/udhr/. Retrieved 27 of October 2009.

Richards, J and Rodgers, T. (2001). Approaches to language teaching and learning. Cambridge: Cambridge University Press.

Richards J, and Lockhart, C. (1994) Reflective teaching in second language classroom. Cambridge: Cambridge University Press.

Rubby, S, and Saraceni, M. (2006). English in the world. Continuum International Publishing Group. New York.

Shön, D. (1991). The reflective practitioner. Ed. Arena. Massachussets.

Shor, I. (1996). When students have power. USA: The University of Chicago Press.

Tsui, A. (2003). Understanding expertise in teaching. Cambridge. Cambridge University Press.

Van Dijk, T. (1987). Ideology. A multidisciplinary approach. London: SAGE Publications.

Wallace, M. (1991) Training foreign language teachers. Cambridge: Cambridge University Press.

Willis, J. (1996). A framework for task based learning, Longman Handbooks for Language Teachers. Longman. Excess.

Wink, J. (2000) Critical pedagogy. Notes from the real 
world. New York: Addison Wesley/ Longman.

THE AUTHOR

SANDRA XIMENA BONILLA holds a BA in Spanish and English teaching from Universidad Pedagógica Nacional and she also holds an M.A. in Applied Linguistics to TEFL from Universidad Distrital Francisco José de Caldas. She is currently coordinating the English 